\title{
NUTRITIONAL STRATEGIES OF SLOVENIAN NATIONAL JUNIOR SWIMMING TEAM
}

\author{
Vesna SIMIČ $^{1}$, Nina MOHORKO ${ }^{1}$ \\ ${ }^{1}$ University of Primorska, Faculty of Health Sciences, Slovenia \\ Corresponding Author: \\ Nina MOHORKO \\ University of Primorska, Faculty of Health Sciences, Polje 42, 6310 Izola, Slovenia. \\ Phone: +38656635801 \\ e-mail: nina.mohorko@fvz.upr.si
}

\section{ABSTRACT}

Purpose: The purpose of our study was to assess the nutritional strategies of Slovenian national junior swimming team and compare them with recommendations of clinical sports nutrition. Competitive young swimmers, namely, have increased energy and nutrient needs compared to general adolescents due to frequent and intense training. Despite some physiological differences if compared with adults, adult sports nutrition recommendations for macronutrients apply to them. Further, literature reports iron, calcium, and vitamin D intake as frequently inadequate.

Methods: Nutritional strategies of 19 members of Slovenian national junior swimming team were assessed retrospectively through 3-day food and activity diaries, questionnaires, anthropometric data including bioimpedance analysis. Energy availability (EA), macronutrient intake and timing, iron, calcium and vitamin D intakes, hydration, consumption of sports food and dietary supplement use were evaluated.

Results: EA in some of male swimmers and in the majority of female swimmers was lower than recommended. Carbohydrate intake was adequate in male swimmers and two thirds of female swimmers. Although average protein intake exceeded the upper recommended limit, some female swimmers did not meet the lower recommended intake limit. Total fat intake was lower than recommended, with saturated fat intake on the upper recommended level. Calcium and iron intake in male swimmers exceeded recommended values, while female swimmers had lower calcium intake than recommended and some had lower iron intake, too. Vitamin D intake was low in all swimmers. Meal timing was adequate in the majority of swimmers, who often reached for dietary supplements, mostly omega 3 fatty acids, multivitamins and magnesium.

Conclusions: Low EA in young competitive swimmers is of concern. More successful, personalised nutrition strategies for young competitive swimmers, focusing on hi- 
gher energy intake and healthy food choices, would contribute to the preservation of their health and further development into top performers.

Keywords: nutrition, young athletes, sport nutrition recommendation, health, performance.

\section{PREHRANSKE STRATEGIJE PLAVALCEV SLOVENSKE KADETSKE IN MLADINSKE REPREZENTANCE}

\section{IZVLE $\check{C} E K$}

Namen: Namen naše raziskave je bil ugotoviti ustreznost uporabljenih prehranskih strategij plavalcev slovenske kadetske in mladinske reprezentance v primerjavi z veljavnimi priporočili klinične športne prehrane. Mladi plavalci, ki tekmujejo, imajo v primerjavi z ostalimi najstniki zaradi pogostih in intenzivnih treningov povečane energijske in prehranske potrebe. Kljub očitnim fiziološkim razlikam, ki jih ločijo od odraslih, veljajo zanje priporočila za vnos makrohranil za odrasle športnike. Med mikrohranili literatura navaja, da so vnosi železa, kalcija in vitamina D pogosto nezadostni.

Metode: Prehranske strategije 19 plavalcev slovenske kadetske in mladinske reprezentance smo retrospektivno ocenili na osnovi 3-dnevnih prehranskih in aktivnostnih dnevnikov, vprašalnika ter podatkov antropometričnih meritev, vključno $z$ bioimpedančno analizo. Ugotavljali smo energijsko razpoložljivost (ER), vnos in časovno razporejanje makrohranil, vnose železa, kalcija in vitamina D, hidracijo, uporabo športne prehrane in prehranskih dopolnil.

Rezultati: ER je bila pri nekaterih moških plavalcih in pri večini plavalk prenizka. Vnosi ogljikovih hidratov so bili primerni pri plavalcih in dveh tretjinah plavalk. Kljub temu, da je ugotovljeni povprečni vnos beljakovin presegal zgornjo priporočeno mejo, nekatere plavalke niso dosegale spodnje priporočene meje. Celokupni vnosi maščob so bili nižji od priporočenih, vnosi nasičenih maščob pa na zgornji meji. Vnos kalcija in železa je pri plavalcih presegal priporočene vrednosti, pri plavalkah pa je bil vnos kalcija in pri nekaterih tudi vnos železa pod priporočeno mejo. Ritem obrokov je bil pri večini ustrezen. Plavalci in plavalke so pogosto uživali prehranska dopolnila, najpogosteje maščobne kisline omega-3, multivitamine in magnezij.

Zaključek: Nizka ER pri mladih plavalcih, ki tekmujejo, je zaskrbljujoča. Bolj uspešne individualne prehranske strategije za mlade plavalce, ki bi se osredotočale na višji energijski vnos in zdravo prehrano, bi prispevale $k$ varovanju njihovega zdravja in razvoju $v$ vrhunske športnike.

Ključne besede: prehrana, mladi športnik, priporočila, zdravje, zmogljivost 


\section{INTRODUCTION}

Young athletes who participate in high intensity sports programs have higher nutritional and energy needs than the general WHO recommendations stated for children and adolescents (Desbrow \& Leveritt, 2015). Competitive young swimmers belong to a group of athletes with increased energy and nutrient needs due to frequent and intense training (Petrie, Stover, \& Horswill, 2004). At the metabolic level, all three energy systems (the high energy phosphagen system, anaerobic glycolysis and aerobic metaboli$\mathrm{sm})$ are involved in all swimming competition disciplines, ranging by duration between 20 seconds $(50 \mathrm{~m})$ and 14.5 minutes $(1,500 \mathrm{~m})$ in junior elite swimmers (Federation Internationale de Natation, 2018). Although adolescents have specific nutritional needs because they differ from adults in energy consumption, substrate consumption during exercise, thermoregulation, sweat mechanism and maintenance of fluid balance as well as other physiological components (Desbrow \& Leveritt, 2015), the sports nutrition principles are similar to those for adults.

For long-term health protection of athletes, adequate energy availability (EA), 45 $\mathrm{kcal} / \mathrm{kg}$ of fat-free mas (FFM) or more, must be provided (Desbrow \& Leveritt, 2015). Sufficient energy and nutrient intake in adolescence is critical for normal growth and development, maintaining health and injury prevention. An adequate nutrition intake also enables optimization of the training process and successful recovery. Adolescence is a crucial period, comprised of intense growth and development, involving the alteration of body composition, metabolic and hormonal fluctuations, maturation of organ systems and formation of nutrient storage, all of which has a potential impact on the individual's health in the future (Sawyer et al., 2012). Long-term suboptimal EA, in the range between 30 and $45 \mathrm{kcal} / \mathrm{kg} \mathrm{FFM}$, or too low EA, under $30 \mathrm{kcal} / \mathrm{kg} \mathrm{FFM}$, leads to relative energy deficiency in sport (RED-S) (Mountjoy et al., 2014). The latter leads to disrupted physiological functions caused by the relative lack of energy, which include lowered metabolic rate, disrupted menstrual function, and compromised bone health, immunity, protein synthesis and cardiovascular health.

Despite the fact that there are potential differences in the ability to store carbohydrates $(\mathrm{CHO})$ and to use substrates during physical activity between adults and children, literature reports that the $\mathrm{CHO}$ needs of young athletes do not differ greatly from the needs of adults (Desbrow et al., 2014). In moderate to high-intensity endurance training, which lasts from 1 to 3 hours per day, $\mathrm{CHO}$ intake of 6 to $10 \mathrm{~g} / \mathrm{kg}$ of body weight (BW) is recommended and in moderate to high intensity exercise, which lasts 4 to 5 hours per day, 8 to $12 \mathrm{~g} \mathrm{CHO} / \mathrm{kg} \mathrm{BW} /$ day is recommended (Burke, Hawley, Wong, \& Jeukendrup, 2011). The recommendations must be individual, dynamic and in accordance with the requirements and goals (Thomas, Erdman, \& Burke, 2016).

Due to the lack of specific research into the protein requirements of adolescent athletes, it is suggested to follow the recommendations for adult athletes $(1.3-1.8 \mathrm{~g}$ protein $/ \mathrm{kg} \mathrm{BW}$ ). Some athletes have increased protein requirements during adolescence compared to the recommended quantities for their age group, especially if they have well-developed muscle mass or if they participate in high intensity exercise programs 
Vesna SIMIČ, Nina MOHORKO: NUTRITIONAL STRATEGIES OF SLOVENIAN NATIONAL JUNIOR SWIMMING TEAM, 15-34

(Boisseau, Vermorel, \& Rance, 2007; Aerenhouts, Deriemaeker, Hebbelinck, \& Clarys, 2011; Aerenhouts, Van Cauwenberg, Poortmans, Hauspie, \& Clarys, 2013).

Dietary fat intake of adolescent athletes should follow general recommendations (Desbrow et al., 2014). According to the National Institute for Public Health (2016) this means that in the 10- to 14-year old age group, fat should represent between 30 and $35 \%$ of total energy intake (EI), while in the 15 - to 18 -year old age group, fat intake should contribute up to $30 \%$ EI, with the note that in physically active individuals this share could be increased to up to $35 \%$ EI. Saturated fat should not exceed $10 \%$ EI (National Institute for Public Health, 2016).

Micronutrient deficiencies have negative impact on health and performance because micronutrients participate in a number of functions in the body. In young athletes, special attention must be paid to iron, calcium and vitamin D intakes (Desbrow \& Leveritt, 2015). Recommendations for iron intake in young athletes do not differ from recommendations for the general population, despite the fact that exercise can cause additional iron loss through sweating or bleeding into the gastrointestinal system or also due to the decomposition of erythrocytes during a long run (Peeling et al., 2009; Koehler et al., 2012). Slovenian adolescent males aged 13 to 18 should therefore consume $12 \mathrm{mg}$ of iron per day and females $15 \mathrm{mg}$ per day (National Institute for Public Health, 2016). The only exception are vegetarian athletes who require higher intakes due to the reduced bioavailability of non-heme iron (Desbrow \& Leveritt, 2015).

Calcium and vitamin D are key nutrients for the development and maintenance of bone mass. Due to intense bone growth during adolescence, calcium needs are increased in both males and females. For 13- to 18-year olds, the recommended daily intake of calcium is $1200 \mathrm{mg}$ (National Institute for Public Health, 2016), which applies to adolescent athletes, too, until there is more research available (Desbrow \& Leveritt, 2015). Vitamin D plays an important role in calcium and phosphate metabolism and calcium integration into bones and teeth, and in the operation of the immune and muscle systems (Desbrow \& Leveritt, 2015). Approximately $90 \%$ of our daily vitamin D requirements are covered by internal synthesis in the skin after exposure to ultraviolet rays; dietary intake contributing only $10 \%$ of the requirements (Koundourakis, Avgoustinaki, Malliaraki, \& Margioris, 2016). In Slovenia, typical nutritional vitamin D intakes (2-4 $\mu \mathrm{g}$ daily) in adolescents in the absence of internal synthesis do not suffice to achieve recommended serum concentrations. The difference between the intake and the recommended value of $20 \mu \mathrm{g}$ must be reached through frequent exposure to the sun and/or taking a vitamin D formulation (National Institute for Public Health, 2016). In latitudes above $35^{\circ}$ north, which applies to Slovenia, the sun rays angle in winter are too oblique for efficient skin vitamin D synthesis (Holick, 2008), apart from that, competitive young swimmers spend long hours practicing indoor also in autumn and spring, which poses them at risk for vitamin D deficiency. Geiker et al. (2017) reported that $45 \%$ of the 29 swimmers (16-24 years old) residing at latitude $55-56^{\circ}$ north had 25-hydroxycholecalciferol below $50 \mathrm{nmol} / \mathrm{L}$ in March and April.

It is known that adolescent athletes have a higher height to body mass ratio (Petrie et al., 2004) and a lower sweating rate (Shibasaki, Inoue, Kondo \& Iwata, 1997) than 
Vesna SIMIČ, Nina MOHORKO: NUTRITIONAL STRATEGIES OF SLOVENIAN NATIONAL JUNIOR SWIMMING TEAM, 15-34

adults. A decreased sweating rate is an advantage in maintaining hydration status and at the same time decreases the success of thermoregulation. Sawka et al. (2007) propose fluid replacement during exercise to such a degree that hypohydration exceeding $2 \%$ is prevented. Desbrow et al. (2014) and Smith, Holmes \& McAllister (2015), who deal with adolescent athletes, recommend the same. Water or milk should not be replaced by sports drinks that contain electrolytes and $\mathrm{CHO}$ because sodium losses through sweating are smaller than in adults (Meyer, Volterman, Timmons, \& Boguslaw, 2012). Sports drinks are recommended only in long-term intense physical activity. Drinking caffeinated energy drinks is advised against in young athletes (Desbrow \& Leveritt, 2015).

The use of sports food (sports drinks, sports bars, sports confectionery, sports gels, liquid meal supplements, ...) is justified in adolescents in cases of long and intensive training (Desbrow et al., 2014). Replacing nutrients with dietary supplements, such as calcium, iron and vitamin D, is also justified when a deficiency is confirmed (International Olympic Committee (IOC), 2011). The use of ergogenics is advised against because it is inappropriate and unnecessary, and in addition their safe use in all age groups has not been confirmed (International Olympic Committee (IOC), 2011).

To fulfil their increased energy requirements, young athletes are recommended three main meals and two snacks (Desbrow \& Leveritt, 2015). A meal rich in CHO (1-4 g CHO/kg BW) is recommended 1-4 hours before activity. During exercise lasting 1-2.5 hours, 30-60 g CHO/h should be consumed. The post exercise meal should contain 1.0-1.2 g CHO/kg BW and $20 \mathrm{~g}$ of protein (Smith et al., 2015). Such a meal, consumed directly or as soon as possible after exercise, enables the refilling of glycogen stores, muscle repair and replaces lost fluid. This is especially important in athletes who compete several days in a row (e.g. in a tournaments) or train more than once per day (Desbrow \& Leveritt, 2015).

The aim of our study was to assess the nutritional strategies of Slovenian national junior swimming team and compare them with recommendations.

\section{METHODS}

\section{Data Collection}

All members of Slovenian national junior swimming team were invited to participate in the study. The eligibility criteria for the national team are determined by the Slovenian swimming federation, which also provided us with the list of swimmers (27 competitive young swimmers). Out of 21 swimmers for whom written consents for personal data processing were obtained, 2 were excluded from analysis due to inadequate food diaries, confining the final sample to 19 competitive young swimmers (Figure 1, Table 1). The data was collected from October to December 2016 and analysed in February 2017. 


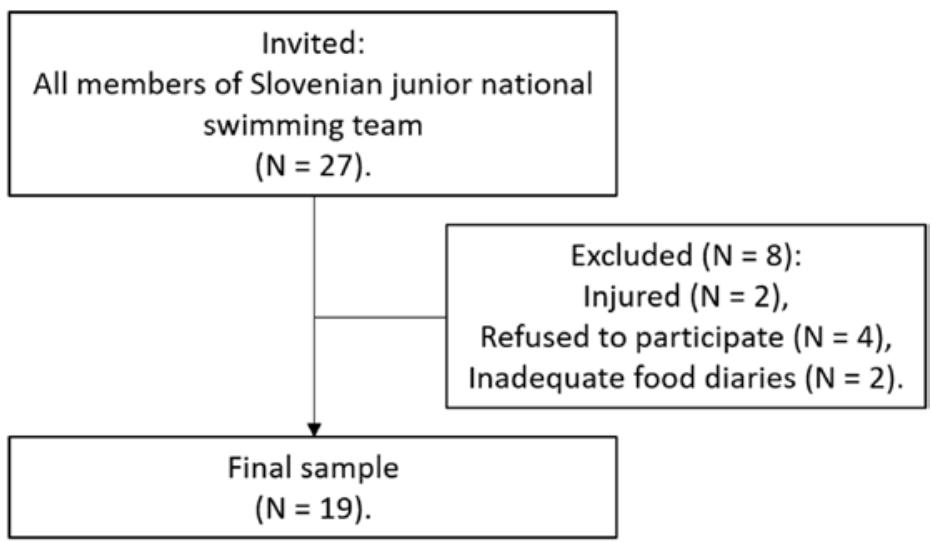

Figure 1: Swimmers flow diagram.

\section{Anthropometric Measurements}

We collected weight and height data from anthropometric measurements regularly performed during preparation training cycles. Swimmers were weighed to the nearest $10 \mathrm{~g}$ (M 304641-01, AED) and height was measured to the nearest $0.5 \mathrm{~cm}$ (Stadiometer, M 304641-01 (ADE). Whole body BIA (BIA 101 Anniversary AKERN, Florence, Italy, medically approved: EN ISO 13485 - ISO 9001) was performed using an alternating sinusoidal electric current of $400 \mu \mathrm{A}$ at an operating frequency of $50 \mathrm{kHz}$ according to recommendations (Kyle et al., 2004) for FFM assessment, that was needed for EA calculation.

\section{Dietary Assessment and Energy Consumption Evaluation}

Data were collected from food and activity diaries. Swimmers were asked to keep 3-day weighted food and activity diaries for three consecutive days (including one weekend day). Swimmers were fully briefed on how to complete the diary and asked to continue their normal diet and physical activity. They were asked to include food labels and recipes for mixed dishes in their record. For each day, they had to record the kind, duration and intensity of the physical activity.

The dietary intake was assessed using Open Platform for Clinical Nutrition (OPEN), that is an online, freely accessible, dietary assessment and planning tool for the analysis of food diary (http://www.opkp.si/en_GB/cms/vstopna-stran). OPEN food composition data was taken from the Slovenian food composition database (Golob et al., 2006); or if not available there, from the Souci, Fachmann \& Kraut Food composition and nutrition tables (2008) and/or from the USDA National Nutrient Database for Standard Referen- 
ce (http://www.ars.usda.gov/Services/docs.htm?docid=8964). Food composition data applied by the OPEN meet the European standard for food data CEN/TC 387, available at http://www.cen.eu/. EI, macronutrient intake and calcium, iron and vitamin D intakes were evaluated.

To examine the suitability of energy consumption, EA was calculated. EA represents the energy that is available for body function, growth and development taking in consideration exercise energy expenditure (EEE) during planned physical activity (Desbrow et al., 2014).

$$
E A=\frac{\mathrm{EI}-\mathrm{EEE}}{\mathrm{FFM}}
$$

Metabolic equivalent of task (MET) was used for EEE evaluation, as suggested by OPEN.

\section{Questionnaire}

Data from a questionnaire that was developed by nutrition expert in charge of nutrition support of national swimming team, were analysed. Swimmers were asked to answer the questionnaire on health parameters (number of infections, menstrual cycle, growth), nutritional habits, timing of meal intake, use of dietary supplements and sports food, as well as type, intensity and the duration of exercise.

\section{Statistical Analysis}

Answers from the questionnaire that refer to sports nutrition recommendations and dietary intake compared to recommended values were processed in Microsoft Excel (IBM Corp. Released 2011), while anthropometric data and dietary intakes were processed with SPSS 20.0 (IBM SPSS Statistics for Windows, Version 20.0. Armonk, NY: IBM Corp.).

The descriptive statistics was used to determine averages, standard deviations and minimum and maximum values. The Shapiro-Wilk test was used for assessing the normality in the distribution of variables, one sample T-test and independent samples T-test were used to evaluate the difference from recommended values and difference between genders. Statistical significance was set at $\mathrm{P}<0,05$. Spearman and Eta correlations were performed to detect different associations between dietary intakes and frequency of infection as well as regularity of menstrual cycle. 
Vesna SIMIČ, Nina MOHORKO: NUTRITIONAL STRATEGIES OF SLOVENIAN NATIONAL JUNIOR SWIMMING TEAM, 15-34

\section{RESULTS}

Characteristics of swimmers grouped by gender are presented in Table 1.

\begin{tabular}{|c|c|c|c|c|c|c|c|c|c|}
\hline 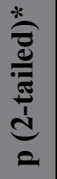 & & $\overline{8}$ & $\stackrel{\overline{8}}{\circ}$ & $\begin{array}{l}8 \\
8 \\
0\end{array}$ & $\begin{array}{l}8 \\
\vdots\end{array}$ & $\begin{array}{l}8 \\
8 \\
0\end{array}$ & $\begin{array}{l}\text { J } \\
8 \\
0\end{array}$ & \begin{tabular}{l}
$\stackrel{\infty}{\infty}$ \\
\multirow{0}{0}{} \\
0
\end{tabular} & $\frac{\dot{J}}{0}$ \\
\hline *ै & & बे & 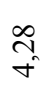 & $\begin{array}{l}+ \\
+ \\
\forall\end{array}$ & $\begin{array}{l}\hat{6} \\
6\end{array}$ & 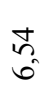 & $\begin{array}{l}\infty \\
\text { ñ } \\
\text { ñ }\end{array}$ & $\frac{N}{0}$ & $\tilde{n}$ \\
\hline \multirow{4}{*}{ 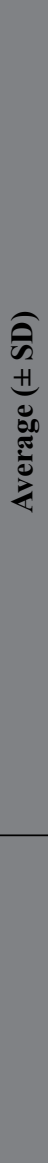 } & 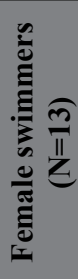 & 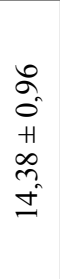 & $\begin{array}{l}\vec{a} \\
\hat{n} \\
+1 \\
\vec{n} \\
\hat{n}\end{array}$ & $\begin{array}{l}n \\
m \\
i n \\
+1 \\
\infty \\
n \\
i n\end{array}$ & 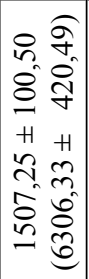 & 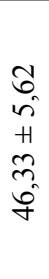 & 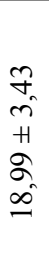 & 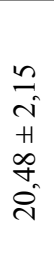 & 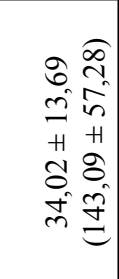 \\
\hline & 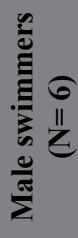 & 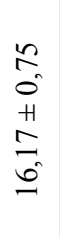 & 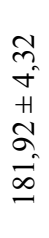 & $\begin{array}{l}\infty \\
\infty \\
+ \\
H \\
\infty \\
\stackrel{2}{2}\end{array}$ & 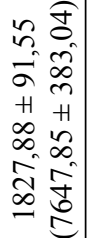 & $\begin{array}{l}\infty \\
\infty \\
+1 \\
\hat{a} \\
\text { î }\end{array}$ & $\begin{array}{l}n \\
\stackrel{1}{1} \\
H \\
\infty \\
0 \\
\pm \\
\Xi\end{array}$ & $\begin{array}{l}\tilde{n} \\
\text { r } \\
+ \\
\stackrel{+}{+} \\
\vec{v}\end{array}$ & 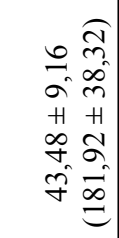 \\
\hline & $\begin{array}{l}\underset{2}{2} \\
\stackrel{\text { II }}{2} \\
\bar{z}\end{array}$ & 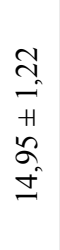 & 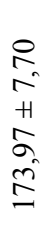 & $\begin{array}{l}\hat{0} \\
0 \\
+1 \\
n \\
\tilde{o} \\
\text { ô }\end{array}$ & 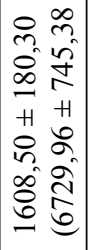 & $\begin{array}{l}2 \\
\text { aे } \\
+1 \\
\infty \\
\cdots \\
\stackrel{n}{n}\end{array}$ & $\begin{array}{l}\hat{A} \\
\text { If } \\
\text { J } \\
\text { In }\end{array}$ & \begin{tabular}{l} 
in \\
i \\
+1 \\
$\infty$ \\
\multirow{2}{*}{}
\end{tabular} & 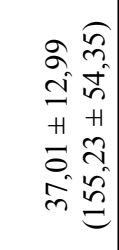 \\
\hline & & 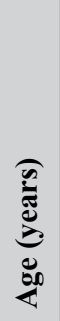 & 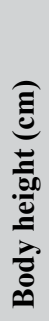 & 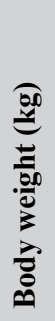 & 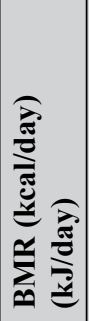 & 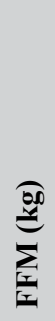 & 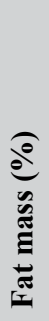 & 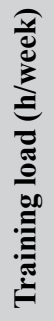 & 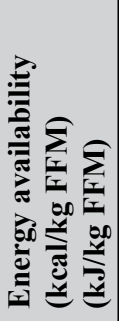 \\
\hline
\end{tabular}


Nutritional data is presented in Table 2 and graphically for each swimmer (Figure 2), coded based on the calculated EA. Female swimmers were assigned codes from 1 to 13 and male swimmers codes from 14 to 19. Each individual's code applies to all displays.

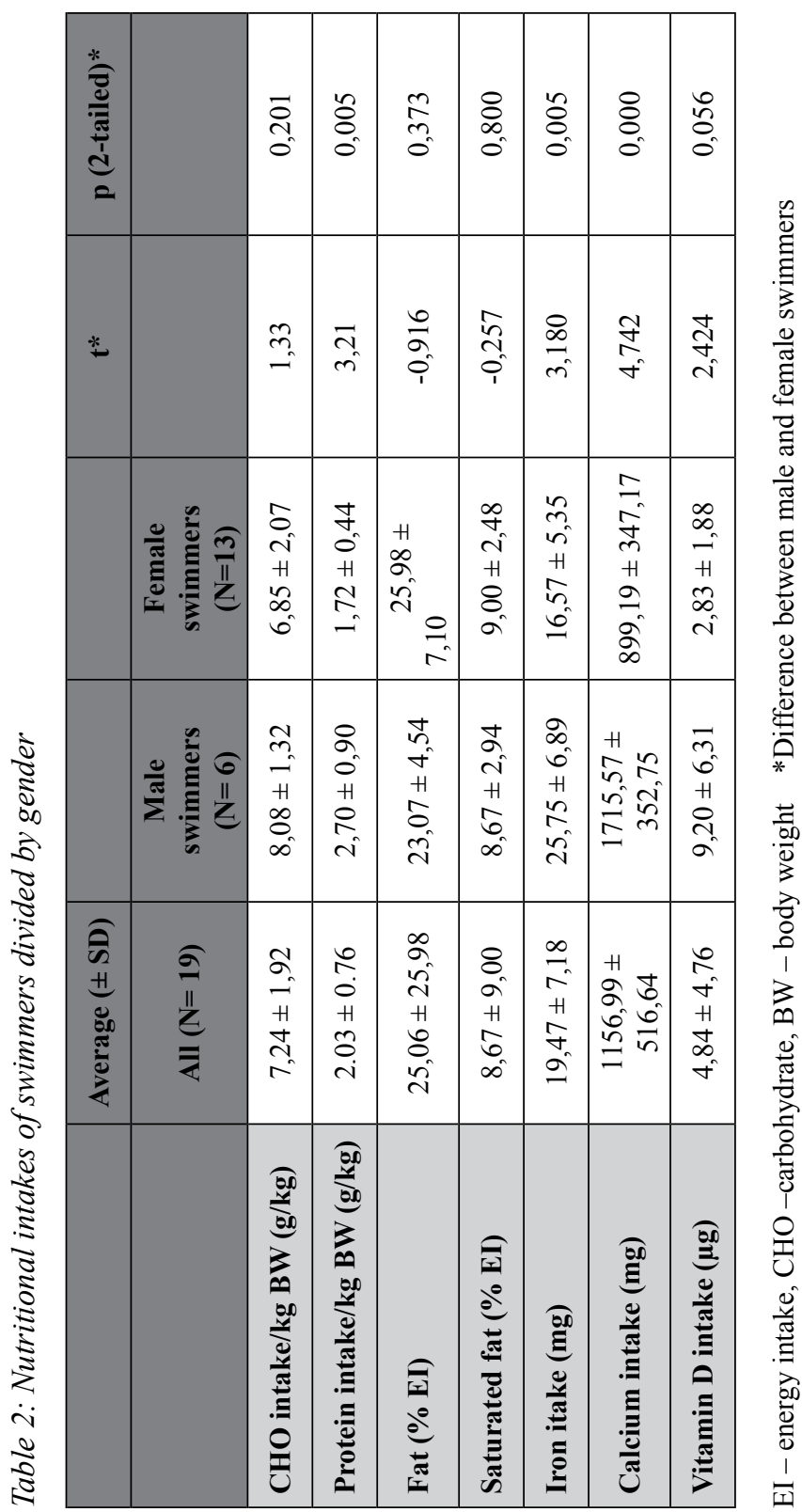




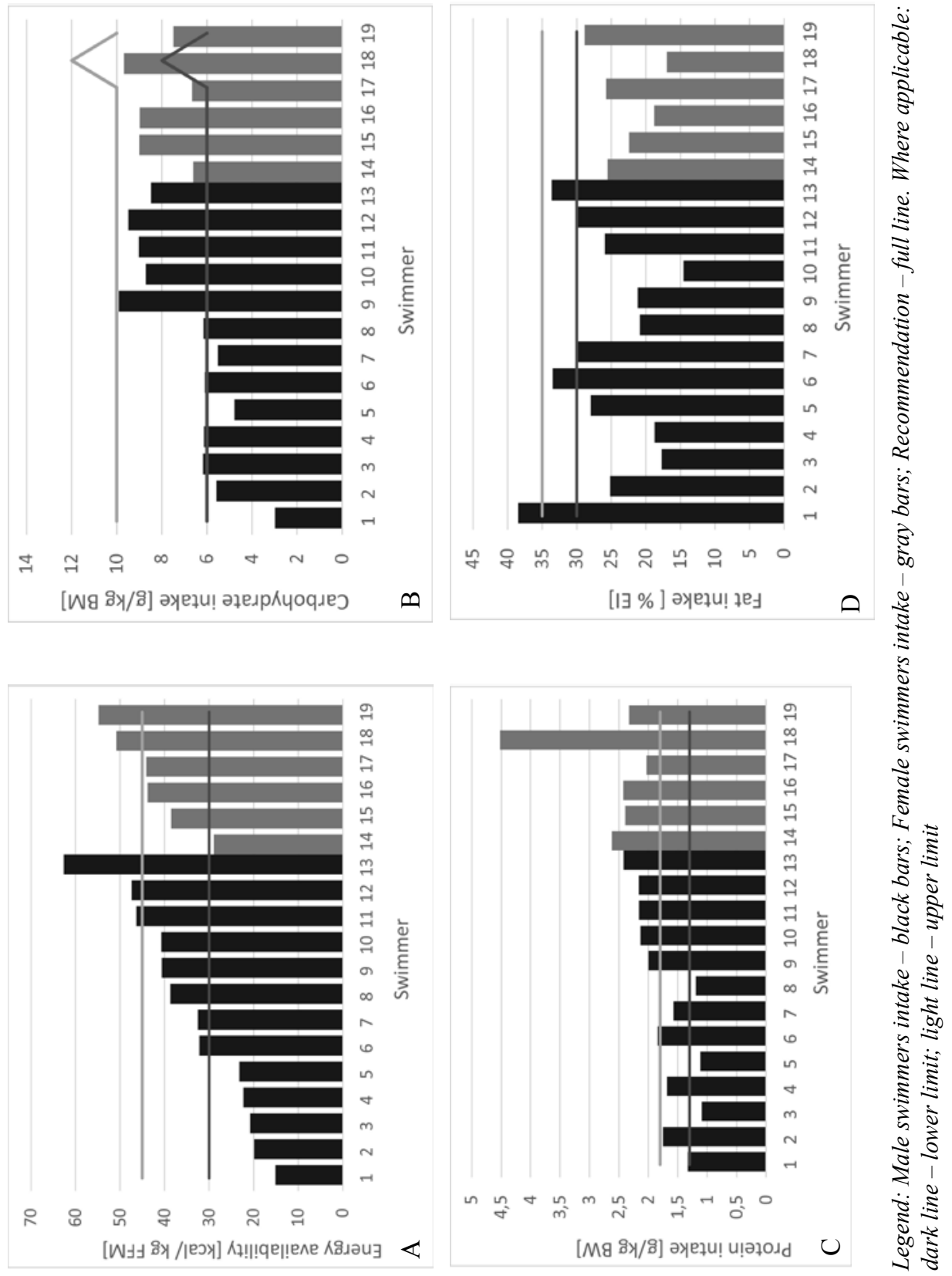

Figure 2a: Nutritional intake of slovenian junior national swimming team compared to recommendations. A EA. B CHO intake. C Protein intake. D Fat intake. 


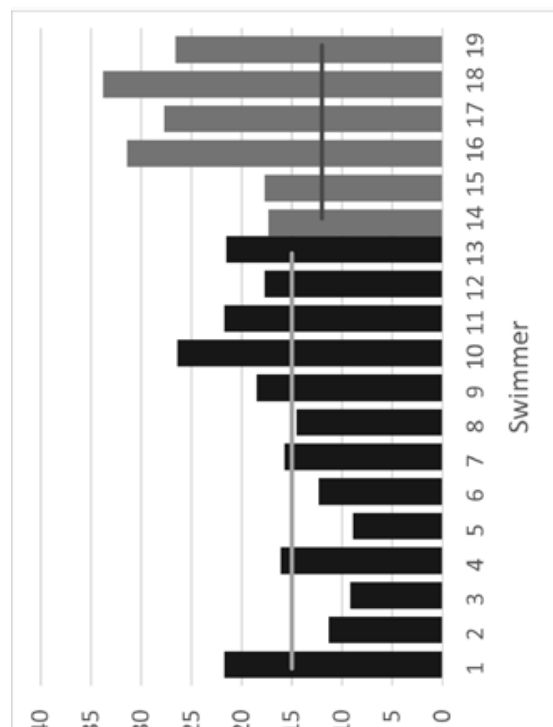

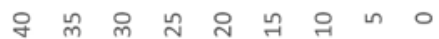

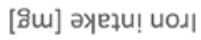
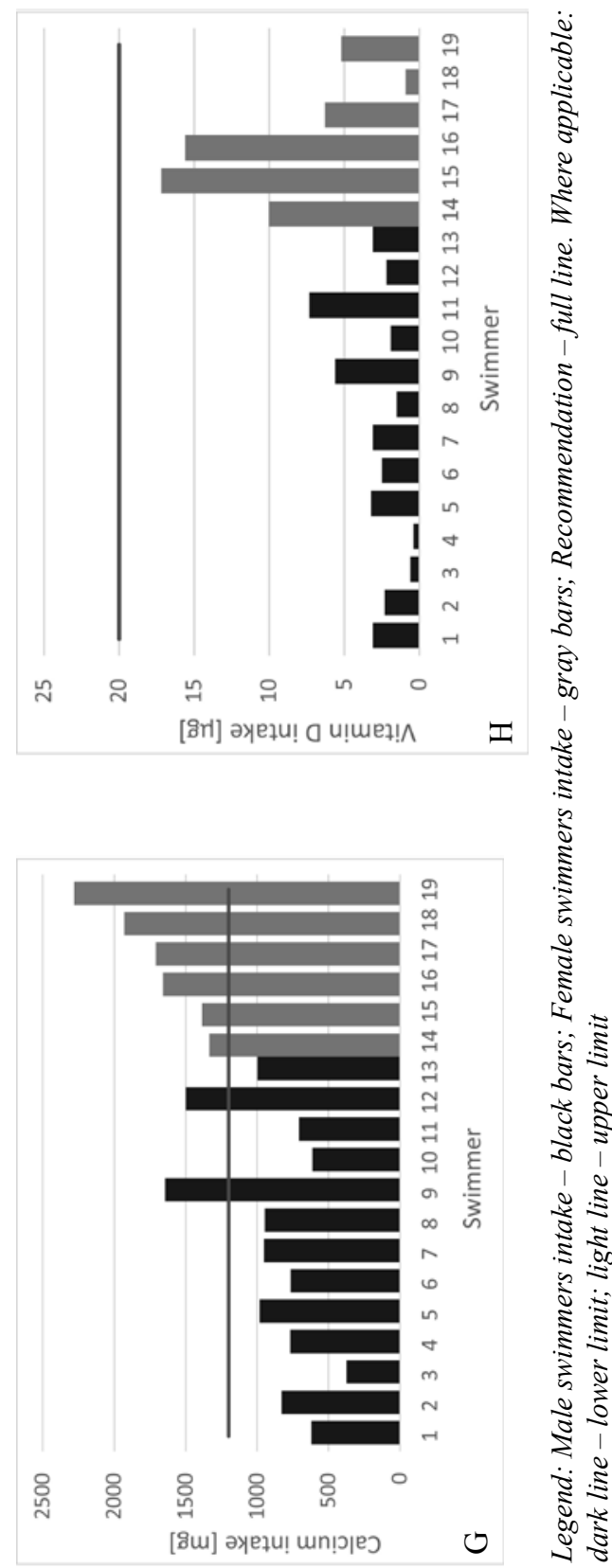

Figure 2b: Nutritional intake of slovenian junior national swimming team compared to recommendations. E Saturated fat intake. F Iron intake. G Calcium intake. H Vitamin D intake. 
EA of the majority of swimmers was between 30 and $45 \mathrm{kcal} / \mathrm{kg}$ FFM, little less than of one third under 30 and only 5 above 45 (Figure 2A). 4 female swimmers with low EA also had a low CHO intake (Figure 2B). All male swimmers exceeded the upper limit for protein intake, while 3 female swimmers did not reach the lower limit of the recommendations, 4 were within the recommended values, and 6 exceeded the upper limit of the recommendations (Figure 2C). The intake of fat was below the recommended limit for all male swimmers and for 8 female swimmers (Figure 2D), while the intake of saturated fat was in accordance with the recommendations in 13 swimmers, whereas 5 female swimmers and 1 male swimmer had intakes that were higher than recommended (Figure 2E). 5 female swimmers had inadequate iron intake (Figure 2F). All male swimmers and 2 female swimmers exceeded the recommended calcium intake, while the remaining 11 female swimmers were under the recommended limit (Figure 2G). Vitamin D intake was below the recommended limit in all swimmers (Figure 2H).

4 female swimmers drank less than $1.5 \mathrm{~L}$ of fluid per day, while the majority of male swimmers $(\mathrm{N}=5)$ and one female swimmer drank more than $3 \mathrm{~L}$ of fluid. The rest drank $1.5-2.5 \mathrm{~L}$ of fluid per day $(\mathrm{N}=6)$ or $2.5-3 \mathrm{~L}(\mathrm{~N}=3)$ on days when they were training. Most of the swimmers drank $0.3-0.8 \mathrm{~L}$ of fluid in one hour of training $(\mathrm{N}=$ 9). 6 swimmers consumed less than that, 3 swimmers drank $0.8-1 \mathrm{~L}$, and 1 swimmer drank $1-1.5 \mathrm{~L}$ of fluid in an hour.

The questionnaire gave us the insight in swimmers' nutritional habits. 17 swimmers (6 male swimmers and 11 female swimmers) regularly consumed fluid during their training, one female swimmer rarely and one never. All swimmers consumed an isotonic beverage with electrolytes during the exercise, while 17 of them never consumed caffeinated energy drinks, and 2 swimmers rarely took them. All swimmers consumed sports food (energy bars, gels, ...), 15 also took dietary supplements, 3 of which took one dietary supplement, 3 took two dietary supplements, 4 took 3 dietary supplements, while 2 took 4 dietary supplements. The most consumed dietary supplement were omega 3 fatty acids $(\mathrm{N}=8$ swimmers), followed by multivitamins $(\mathrm{N}=6)$ and magnesium $(\mathrm{N}=5), 4$ took iron, glutamine or vitamin C and 3 took vitamin D. Vitamin B, creatine, Q10 or branched amino acids were taken by 1 swimmer each.

The majority $(\mathrm{N}=15)$ consumed five meals or more per day. Others consumed four $(\mathrm{N}=2)$ or three $(\mathrm{N}=2)$ meals per day, but none less than that. The majority of swimmers $(\mathrm{N}=14)$ also always consumed a balanced meal $2-3$ hours before training, 4 rarely and 1 never. The majority $(\mathrm{N}=12)$ consumed a $\mathrm{CHO}$ rich meal one hour before training. Almost all $(\mathrm{N}=18)$ regularly consumed a meal rich in $\mathrm{CHO}$ and protein within an hour after training, while one swimmer rarely did so. To the question "Do you consume a protein supplement within an hour after training?" 6 swimmers answered "always", 5 answered that they "rarely consumed protein in the form of a supplement" and 8 answered "never".

We also determined the frequency of infections in competitive young swimmers. The majority $(\mathrm{N}=13)$ fell ill $1-2$ times per year, 4 more frequently and 2 never. Only 3 female swimmers had a regular menstrual cycle. 2 females in the group who had never had a period $(\mathrm{N}=6)$ were over 15 years old. 4 female swimmers had an irregular menstrual cycle. The frequency of infection was not statistically significantly associated 
with energy availability $(\rho=-0.223, p=0.360)$, CHO $(\rho=0.099, p=0.686)$, protein $(\rho$ $=-0.066, p=0.787)$ nor fat $(\rho=-0.354, p=0.138)$ intake. The regularity of menstrual cycles in females was not statistically significantly associated with energy availability $\left(\eta=0.186, \eta^{2}=0.340, p=0.839\right)$, CHO $\left(\eta=0.264, \eta^{2}=0.070, p=0.696\right)$, protein $(\eta$ $\left.=0.543, \eta^{2}=0.295, p=0.175\right)$ nor fat intake $\left(\eta=0.444, \eta^{2}=0.197, p=0.333\right)$, either.

\section{DISCUSSION}

The first systematic insight into the nutrition status of young competitive athletes in Slovenia showed some inadequate intake of nutrients that may influence the performance and health of young athletes.

Some exceptionally low EA values (min. $=15.1 \mathrm{kcal} / \mathrm{kg}$ FFM) and the fact that almost three quarters of the swimmers did not achieve the recommended EA values indicated that the EI in some young male swimmers and mostly in female swimmers were too low and needed improvement, because long-lasting low relative EA influences a number of organic systems and may in the short and long-term compromise health and performance (Mountjoy et al., 2014). The calculated low EA may also be due to methodological causes. It is known that in determining dietary intake with the use of a food diary, inaccuracies may occur that may be the consequence of a changed diet due to recording into the food diary itself, incorrectly recording foods that are or are not desired in order to improve the impression on what was eaten, or actual errors that occur in the weighing or description of consumed quantities (Burke, 2001). It is also known that as many as $80 \%$ of participants report too low quantities of food intake, with reported quantity being up to $20 \%$ lower than actual intake (Black et al., 1993). Another problem could be the EEE, because it was not measured but calculated based on reported time and type of exercise, using MET. The small sample of swimmers and unequal representation of genders also represented an additional restriction.

Based on reported training load, 18 swimmers required CHO intake of 6 to $10 \mathrm{~g} / \mathrm{kg}$ BW, while one swimmer had higher requirements due to a higher exercise load ( $8-12$ $\mathrm{g} / \mathrm{kg} \mathrm{BW}$ ). While all male swimmers had adequate $\mathrm{CHO}$ intake, 4 female swimmers did not reach the lower recommended intake limit. Inadequate intake leads to inadequate glycogen stores and the onset of fatigue, which, in connection with low EA that was identified in all of them, has a negative effect on health and performance (Loucks, Kiens, \& Wright, 2011). An adequate intake of CHO also prevents protein catabolism. Burke et al. (2011) define CHO availability as a dynamic measure of suitable CHO intake, both on daily basis and on strategic time points around important exercise sessions as high $\mathrm{CHO}$ availability provides $\mathrm{CHO}$ for muscle and nervous system and has thus the potential to enhance performance and recovery at key times. We examined the adequacy of meal timing and composition around training with a questionnaire. 14 swimmers followed the recommendations and always consumed a balanced meal, including CHO, $2-3$ hours prior to training. In addition, 12 consumed one more meal rich in $\mathrm{CHO}$ within one hour prior to exercise, which is an effective strategy for ensuring an additional 
energy source for working muscles and the central nervous system (Jeukendrup \& Cronin, 2011). During their exercise, all swimmers replaced fluids, $\mathrm{CHO}$ and electrolytes. As many as 18 swimmers consumed a $\mathrm{CHO}$ and protein rich meal after training. All the above shows that top young Slovenian swimmers mainly use nutrition strategies in accordance with recommendations before, during and after training. However, since $\mathrm{CHO}$ availability covers both, daily intake and meals around exercise, inadequate daily CHO intake in 4 female swimmers means low CHO availability, which means their glycogen stores are not optimally replenished which can affect performance, both on training and competition (Burke et al., 2011). More emphasis should therefore be placed on adequate daily $\mathrm{CHO}$ intake in female young swimmers. This would enable them to reach adequate $\mathrm{CHO}$ availability and $\mathrm{EA}$ and consequently adequate glycogen stores and prevent them from fatigue and muscle catabolism.

The protein intake of all male swimmers and 6 female swimmers exceeded the upper recommended limit, $1.8 \mathrm{~g} / \mathrm{kg} \mathrm{BW} /$ day, despite EA being too low in 4 male swimmers and 3 female swimmers. The literature reports that young athletes who have adequate EA reach or exceed protein intake recommendations (Petrie et al., 2004; Heanley, O'Connor, Giifford, \& Naughton, 2010; Gibson, Stuart-Hill, Martin, \& Gaul, 2011). After training, 3 male swimmers and 3 female swimmers always consumed protein in the form of a supplement, 1 male and 4 female swimmers did so occasionally, while the others did not consume protein in the form of supplements. The use of protein supplement in young athletes could be justified merely due to their practicality, however, food sources of protein would be a better choice, especially because protein needs can be fulfilled within normal EA. On the other hand, 3 female swimmers (all 3 with low EA) did not reach the lower recommended protein intake, $1.3 \mathrm{~g} / \mathrm{kg} \mathrm{BW} /$ day. An inadequate protein intake or a low $\mathrm{EA}$, where part of the protein is used as a substrate in the process of energy acquisition, could potentially lower the amino acid availability for basic physiological functions (Petrie et al., 2004; Campbell et al., 2007). Therefore, low protein intake is problematic, and even (too) high intake in the context of low EA does not guarantee appropriate protein availability. The average EA in female swimmers was lower than the recommended limit, and therefore they were more prone to protein deficiency in our sample than male swimmers. To prevent protein and energy deficiency, we would suggest to fulfil protein needs by increasing EI through normal food.

No guidelines or recommendations mention the absolute fat content in an individual's diet, the values refer to the percentage of EI provided by fat. Our swimmers had low fat intake, contrary to literature reports (Croll et al., 2006; Juzwiak, Amancio, Vitalle, Pinheiro, \& Szejnfeld, 2008), which state that the fat intake in young athletes usually exceeds $30 \%$ of EI. This lack of fat may be the cause of the low EA that was noticed mainly in female swimmers, which is why we, in line with other authors, recommend that young athletes be encouraged to eat fish and unsaturated fats from plant sources and to avoid the consumption of saturated fats from fried foods and baked goods as well as fats of animal origin (Desbrow et al., 2014) which contribute to higher saturated fat intake. Indeed, the intake of saturated fat in some swimmers was above the upper recommended value. 
Vesna SIMIČ, Nina MOHORKO: NUTRITIONAL STRATEGIES OF SLOVENIAN NATIONAL JUNIOR SWIMMING TEAM, 15-34

Three key micronutrients for young athletes can be identified from the literature: iron, calcium and vitamin D (Desbrow et al., 2014; Smith et al., 2015). The average iron intake in female swimmers was sufficient, but individual intake was insufficient in 5 female swimmers. The findings partially correspond to the findings of other authors who state that the dietary intake of iron in young male athletes exceeds the recommendations, while in females they are within the recommended limits (Juzwiak et al., 2008; Heanley, et al., 2010; Gibson et al., 2011; Martinez et al., 2011). Since low iron stores are usually observed in female swimmers, regular supervision of iron status is necessary as well as early detection of low iron stores and appropriate intervention in order to increase iron intake or to increase the iron bioavailability. Taking iron as a dietary supplement is justified only in cases of proven deficiency (Desbrow et al., 2014).

The literature states that young athletes achieve only one half of the recommended calcium intake (Gibson et al., 2011; Juzwiak et al., 2008), which was not the case in our study. Calcium intake was above the recommended values in male swimmers, but under the recommended limit in female swimmers, which is in line with Martinez et al. (2011). Encouraging milk and dairy consumption would not only improve calcium intake, but also fat and protein intake and EA (Fayet, Ridges, Wright, \& Petocz, 2013).

The estimated dietary intake of vitamin D was lower in female swimmers than in male swimmers. A comparison with recommendations was not possible as they define vitamin D requirements that may be met through dietary intake as well as through internal synthesis. Serum concentrations of 25-hydroxycholecalciferol would give us a better insight into vitamin D status, however considering our latitude (above 35th parallel north), long hours spent indoors due to training and the low dietary intake of vitamin D in female swimmers, we can suspect that this group is at risk of vitamin D deficiency. Due to the high physical load we are concerned that the current nutrition strategies of some competitive female swimmers together with calcium deficiency and low EA may have a negative impact on bone health, which is further exacerbated by the physical activity in water which lowers the workload against gravity (Gomez-Bruton et al., 2017). Regular monitoring of vitamin $D$ status is necessary in athletes at increased risk of deficiency and suitable supplementation should be advised in case of discovered inadequacy (Desbrow et al., 2014).

Fluid intake was assessed using a questionnaire as we were not able to assess it based on the food diary due to insufficient data. The problem with sufficient fluid intake is that there are noticeable individual differences between athletes, due to which there are no concrete fluid intake recommendations. Reference values for nutrient intake (German nutrition society (DGE), 2004) state that moderately active 15-year-old adolescents or younger should consume $1330 \mathrm{~mL}$ of fluid daily, while those over 15 years old should consume $1530 \mathrm{~mL}$. From the questionnaire, we discovered that 4 female swimmers drank less than $1.5 \mathrm{~L}$ of fluid per day on training days, which we can certainly assess as inadequate as that is the recommended intake for non-active individuals. Adams et al. (2016) discovered that as many as $67-78 \%$ (depending on the method) of swimmers aged 8 to 17 came to morning training in a hypohydrated state. Due to significant differences between individuals and physical activities, Australian dieticians 
and sports nutrition specialists (Desbrow et al., 2014) recommend regular monitoring of fluid intake needs by weighing before and after training. We do not have the data on individual weight losses during exercise and cannot estimate the quantitative adequacy of fluid replacement. Drinking energy drinks containing caffeine is not recommended in this age group (Desbrow \& Leveritt, 2015). Only 2 young swimmers (10.5\%) reported consuming energy drinks, which is a good result, as O'Dea (2003) found that in the age group between 11 and 18 years old as many as $42.3 \%$ of otherwise moderately active children consumed energy drinks.

All the competitive young swimmers in the sample consumed sports food, which is justified considering their heavy training load. They also often used dietary supplements $(78.8 \%$ ), possibly including more than one supplement (up to four), which is a little more than reported by McDowall (2007), who found the prevalence between $22 \%$ and $71 \%$. The competitive young swimmers most commonly took omega-3 fatty acids, multivitamins and magnesium. The supplementation of nutrients is considered justified when a deficiency is discovered or if needs cannot be met through nutrition. Based on our results, competitive young swimmers should consider supplementing vitamin D. Even though the use of ergogenic aids for better performance is inappropriate and unnecessary and their safe use has not been confirmed in this age group, we discovered that 1 swimmer used creatine. Competitive young swimmers should be familiarized with the risks of using dietary supplements because they may not be safe, may be disallowed or ineffective or even contaminated with banned substances (Desbrow et al., 2014). They should be encouraged to meet their nutritional requirements through the correct choice of foods and not through supplements.

It is known that low EA is a risk factor for low immune function and increased susceptibility to infection (Montenero, Lopez-Varela, Nova, \& Marcos, 2002). Despite the fact that there was the possibility that the reported intake was too low, the low EA that we noticed in 14 of the competitive young swimmers indicated an increased risk of infection that we did not manage to prove in our sample of 19 swimmers. We also did not manage to determine a correlation between the frequency of infection and the intake of other macronutrients that are connected with immune system function.

Low EA influences the regularity of the menstrual cycle and causes functional hypothalamic menstrual dysfunction, which has a negative impact on bone health as it leads to decreased formation of new bone tissue and increased resorption of existing bone tissue, which represents the second largest protein store after muscles (Loucks et al., 2011). Low EA in our female swimmers is of concern, as only 3 female swimmers had reported regular menstrual cycle. In the group of 6 female swimmers that had never had their period, there were 2 swimmers over the age of 15 , thus expressing primary amenorrhea. For those with irregular menstrual cycles $(\mathrm{N}=4)$, we did not manage to acquire the information on the length of the absence of their period, so we cannot discuss secondary amenorrhea in our swimmers. We did not find a statistically significant correlation between EA, intakes of $\mathrm{CHO}$, protein and fat and menstrual cycle regularity. Nevertheless, we find alarming to identify 4 young female swimmers (nearly $1 / 3$ of female swimmers) with low EA, low $\mathrm{CHO}$ intake (one also with low protein intake) 
as well as low calcium and vitamin D intake. Only one of them stated that she had a regular menstrual cycle. Since female swimmers, due to their high training load, belong in the group with a high risk of RED-S, and consequently of functional hypothalamic menstrual dysfunction, which may also have long-term negative effects on health, we believe that the menstrual cycle must be monitored in competitive young swimmers and measures be taken in cases where a dysfunction is discovered. Measures include an increase in EI, a decrease in EEE or both (Mountjoy et al., 2014; De Souza et al., 2014).

Hereby, it is important to emphasize the necessity of adaptation of strategies to specific individual, for they have to be aligned with their individual goals, their ability to execute and potential intolerance for certain specific nutrients. Those strategies must take into consideration the athlete's favourite foods as well as individual responses to strategies themselves (Thomas et al., 2016).

\section{CONCLUSIONS}

Comparison of applied nutrition strategies with the current recommendations of clinical sports nutrition in young Slovenian competitive swimmers enabled us to identify dietary deficits, especially among female swimmers, where too low EI leads to insufficient macronutrient and micronutrient intake and too low EA, which can lead to a decline in performance and even seriously compromise their health. The acquired information can enable dietitians to prepare more successful, personalised nutrition strategies for young competitive swimmers, hence contribute to the preservation of their health and their development into top athletes.

\section{Acknowledgement}

The authors thank Slovenian Swimming Federation, coaches, swimmers and their parents for showing a high level of support for the research.

\section{REFERENCES}

Adams, J. D., Kavouras, S. A., Robillard, J. I., Bardis, C. N., Johnson, E. C., Ganio, M. S., ... White, M. A. (2016). Fluid balance of adolescent swimmers during training. Journal of Strength and Conditioning Research, 30(3), 621-625. doi: 10.1519/ JSC.0000000000001132 VIEW ITEM

Aerenhouts, D., Deriemaeker, P., Hebbelinck, M., \& Clarys, P. (2011). Energy and macronutrient intake in adolescent sprint athletes: A follow-up study, Journal of Sports Sciences, 29(1), 73-82, doi: 10.1080/02640414.2010.521946 VIEW ITEM

Aerenhouts, D., Van Cauwenberg, J., Poortmans, J. R., Hauspie, R., \& Clarys, P. (2013). Influence of growth rate on nitrogen balance in adolescent sprint athletes. In- 
Vesna SIMIČ, Nina MOHORKO: NUTRITIONAL STRATEGIES OF SLOVENIAN NATIONAL JUNIOR SWIMMING TEAM, 15-34

ternational journal of sport nutrition and exercise metabolism, 23(4), 409-417. doi: 10.1123/ijsnem.23.4.409 VIEW ITEM

Black, A. E., Prentice, A. M., Goldberg, G. R., Jebb, S. A., Bingham S. A., Livingstone, M. B., \& Coward, W. A. (1993). Measurements of total energy expenditure provide insights into the validity of dietary measurements of energy intake. Journal of American Dietetic Association, 93(5), 572 - 579. doi: 10.1016/0002-8223(93)91820-G VIEW ITEM

Boisseau, N., Vermorel, M., \& Rance, M. (2007). Protein requirements in male adolescent soccer players. European Journal of Applied Physiology, 100(1), 27-33. doi: 10.1007/ s00421-007-0400-4 VIEW ITEM

Burke, L. (2001). Energy needs of athletes. Canadian Journal of Applied Physiology, 26(S 1), 202-219. doi: 10.1139/h2001-055 VIEW ITEM

Burke, L. M., Hawley, J. A., Wong, S. H., \& Jeukendrup, A. E. (2011). Carbohydrates for training and competition. Journal of Sports Sciences. 29(S1), 17-27. doi: 10.1080/02640414.2011.585473 VIEW ITEM

Campbell, B., Kreider, R. B., Zigenfuss, T., La Bounty, P., Roberts, M., Burke, L., ... Antonio, H. (2007). International Society of Sports Nutrition position stand: protein and exercise. Journal of International Society of Sports Nutrition, 4(8), 1-7. doi: 10.1186/1550-2783-4-8 VIEW ITEM

Croll, J. K., Neumark-Sztiner, D., Story, M., Wall, M., Perry, C., \& Harnack, L. (2006). Adolescents involved in weight-related and power team sports have better eating patterns and nutrient intakes than non-sport-involved adolescents. Journal of American Dietetic Association, 106(5), 709-717. doi: 10.1016/j.jada.2006.02.010 VIEW ITEM

Desbrow, B., \& Leveritt, M. (2015). Nutritional issues for young atlethes: children and adolescents. In: Burke, L. in Deakin, V., (Eds.), Clinical Sports Nutrition. Sidney, Australia: MCGraw Hill.

Desbrow, B., McCormack, J., Burke, L. M., Cox, G. R., Fallon, K., Hislop, M., ... Leveritt, M. (2014). Sports Dietitians Australia position statement: sports nutrition for the adolescent athlete. International Journal of Sport Nutrition and Exercise Metabolism, 24(5), 570-584. doi: 10.1123/ijsnem.2014-0031 VIEW ITEM

De Souza, M. J., Nattiv, A., Joy, E., Misra, M., Williams, N. I., Mallinson, R. J., ... Matheson, G. (2014). Female Athlete Triad Coalition consensus statement on treatment and return to play of the female athletetriad: 1st International Conference held in San Francisco, California, May 2012 and 2nd International Conference held in Indianapolis, Indiana, May 2013. British Journal of Sports Medicine, 48(4), 289. doi: 10.1136/ bjsports-2013-093218 VIEW ITEM

Fayet, F., Ridges, L. A., Wright, J. K., \& Petocz, P. (2013). Australian children who drink milk (plain or flavored) have higher milk and micronutrient intakes but similar body mass index to those who do not drink milk. Nutrition Research, 33(2), 95-102. doi: 10.1016/j.nutres.2012.12.005 VIEW ITEM

Federation Internnationale de Natation. (2018) Fina 50m-pool world junior records (as of December 3, 2018). (Dec $8^{\text {th }}$, 2018) Retrieved from http://www.fina.org/sites/default/ files/wr jir dec 3 2018.pdf

German nutrition society (DGE), 2004. Reference values for nutrient intake $1^{\text {st }}$ edition, Ljubljana: Ministry of health, Republic of Slovenia.

Gibson, J., Stuart-Hill, L., Martin, S., \& Gaul, C. (2011). Nutrition status of junior elite Canadian female soccer athletes. International Journal of Sport Nutrition and Exercise Metabolism, 21(6), 507-514. doi: 10.1123/ijsnem.21.6.507 VIEW ITEM 
Geiker, N. R. W., Larsen, R., Hansen, M., Jørgensen, N. R., Jakobsen, J., Hansen, B. S., ... Bügel, S. (2017). Vitamin D status and muscle function among adolescent and young swimmers. International Journal of Sport Nutrition and Exercise Metabolism, 27(5), 399-407. doi: 10.1123/ijsnem.2016-0248 VIEW ITEM

Golob, T., Stibilj., V., Žlender, B., Kropf, U., Korošec, M., Polak, T., ... Čandek Potokar, M. (2006), "Slovenian Food Composition Tables - Meat and Meat Products," University of Ljubljana, Biotechnical Faculty.

Gomez-Bruton, A., Montero-Marín, J., González-Agüero, A., Gómez-Cabello, A., García-Campayo, J., Moreno, L. A., ... Vicente-Rodríguez, G. (2017). Swimming and peak bone mineral density: a systematic review and meta-analysis, Journal of Sports Sciences, 36(4), 365-377. doi: 10.1080/02640414.2017.1307440 VIEW ITEM

Heanley, S., O'Connor, H., Giifford, J., \& Naughton, G. (2010). Comparison of strategies for assessing nutritional adequacy in elite female athletes' dietary intake. International Journal of Sport Nutrition and Exercise Metabolism, 20(3), 245-256. doi: 10.1123/ijsnem.20.3.245 VIEW ITEM

Holick, M. F. (2008) Sunlight, UV-radiation, vitamin D and skin cancer: how much sunlight do we need?. In: Reichrath J. (eds) Sunlight, Vitamin D and Skin Cancer. (Advances in Experimental Medicine and Biology, Vol. 624, pp. 1-15). doi: 10.1007/978-0-38777574-6_1 VIEW ITEM

International Olympic Committee. (2011). IOC consensus statement on sports nutrition 2010. Journal of Sports Sciences, 29(S1), S3-S4. doi:10.1080/02640414.2011.619349 VIEW ITEM

Jeukendrup, A. \& Cronin, L. (2011). The elite young athlete. (Medicine and Sport Science, Vol. 56, pp. 47-58). doi: 10.1159/000320630 VIEW ITEM

Juzwiak, C. R., Amancio, O. M. S., Vitalle, M. S. S., Pinheiro, M. M., \& Szejnfeld, V. L. (2008). Body composition and nutritional profile of male adolescent tennis players. Journal of Sports Sciences, 26(11), 1209-1217. doi: 10.1080/02640410801930192 VIEW ITEM

Koehler, K., Braun, H., Achtzehn, S., Hildebrand, U., Predel, H-G., Mester, J., \& Schänzer, W. (2012). Iron status in elite young athletes: gender-dependent influences of diet and exercise. European journal of applied physiology, 112(2), 513-523. doi: 10.1007/s00421-011-2002-4 VIEW ITEM

Koundourakis, N., Avgoustinaki, P. D., Malliaraki, N., \& Margioris, A. N. (2016). Muscular effects of vitamin D in young athletes and non-athletes and in the elderly. Hormones. 15(4), 471-488. doi: 10.14310/horm.2002.1705 VIEW ITEM

Kyle, U., Boseaus, I., De Lorenzo, A., Deurenberg, P., Elia, M., Gomez, M., ... Pichard, C. (2004). ESPEN Guidelines. Bioelectrical impedance analysis - part 2: review of principles and methods. Clinical Nutrition, 23(6), 1430-1453. doi: 10.1016/j. clnu.2004.09.012 VIEW ITEM

Loucks, A., Kiens, B., \& Wright, H. (2011). Energy availability in athletes. Journal of Sports Sciences, 29(S1), S7-S15, doi: 10.1080/02640414.2011.588958 VIEW ITEM

Martinez, S., Pasquarelli, B. N., Romaguera, D., Arasa, C., Tauler, P., \& Aguilo, A. (2011). Anthropometric characteristics and nutritional profile of young amateur swimmers. Journal of Strength and Conditioning Research, 25(4), 1126-1133. doi: 10.1519/ JSC.0b013e3181d4d3df VIEW ITEM

McDowall, J. A. (2007). Supplement use by young athletes. Journal of Sports, Science, and Medicine, 6(3), 337-342. VIEW ITEM 
Meyer, F., Volterman, K. A., Timmons, B. W., \& Boguslaw, W. (2012). Fluid balance and dehydration in the young athlete: Assessment considerations and effects on health and performance. American Journal of Lifestyle Medicine, 6(6), 489-501. doi: 10.1177/1559827612444525 VIEW ITEM

Montenero, A., Lopez-Varela, S., Nova, E., \& Marcos, A. (2002). The implication of the binomial nutrition-immunity on sportswomen's health. European Journal of Clinical Nutrition, 56, 38-41. doi: 10.1038/sj.ejcn.1601483 VIEW ITEM

Mountjoy, M., Sundgot-Borgen, J., Burke, L., Carter, S., Constantini, N., Lebrun, C., ... Ljungqvist, A. (2014). The IOC consensus statement: beyond the Female Athlete Triad-Relative Energy Deficiency in Sport (RED-S). British Journal of Sports Medicine, 48(7), 491-497. doi: 10.1136/bjsports-2014-093502 VIEW ITEM

National institut for public health. (2016). Referenčne vrednosti za energijski vnos ter vnos hranil [Reference values for nutrient intake]. Retrieved from http://www.mz.gov. si/fileadmin/mz.gov.si/pageuploads/javno_zdravje_2015/foto_DJZ/prehrana/2016_referencne vrednosti za energijski vnos ter vnos hranil 17022016.pdf

O'Dea, J. A., (2003). Consumption of nutritional supplements among adolescents: usage and perceived benefits. Health and Education Research, 18(1), 98-107. doi: 10.1093/ her/18.1.98 VIEW ITEM

Peeling, P., Dawson, B., Goodman, C., Landers, G., Wiegerinck, E. T., Swinkels, D. W., \& Trinder, D. (2009). Cumulative effects of consecutive running sessions on hemolysis, inflammation and hepcidin activity. European Journal of Applied Physiology, 106(1), 51-59. doi: 10.1007/s00421-009-0988-7 VIEW ITEM

Petrie, H. J., Stover, E. A. \& Horswill, C. A. (2004). Nutritional concerns for the child and adolescent competitor. Nutrition, 20(7-8), 620-631. doi: 10.1016/j.nut.2004.04.002 VIEW ITEM

Sawka, M., Burke, L., Eichner, E., Maughan, R., Montain, S., \& Stachenfeld, N. (2007). American College of Sports Medicine position stand. Exercise and fluid replacement. Medicine and Science in Sports and Exercise, 39(2), 377-390. doi: 10.1249/ mss.0b013e31802ca597 VIEW ITEM

Sawyer, S. M., Afifi, R. A., Bearinger, L. H., Blakemore, S. J., Dick, B., Ezeh, A. C., \& Patton, G. C. (2012). Adolescence: a foundation for future health. The Lancet, 379(9826), 1630-1640. doi: 10.1016/S0140-6736(12)60072-5 VIEW ITEM

Shibasaki, M., Inoue, Y., Kondo, N., \& Iwata, A. (1997). Thermoregulatory responses of prepubertal boys and young men during moderate exercise. European Journal of Applied Physiology and Occupational Physiology, 75(3), 212-218. doi: 10.1007/s004210050150 VIEW ITEM

Smith, J. W., Holmes, M. E., \& McAllister, M. J. (2015). Nutritional considerations for performance in young athletes. Journal of sports medicine, 2015(734649), 1-13. doi: 10.1155/2015/734649 VIEW ITEM

Souci, S. W., Fachmann W., \& Kraut, H. (2008). Food composition and nutrition tables, 7th ed. Stuttgart, Germany: MedPharm Scientific Publishers.

Thomas, D. T., Erdman, K. A., \& Burke, L. M. (2016). Position of the Academy of Nutrition and Dietetics, Dietitians of Canada, and the American College of Sports Medicine: Nutrition and athletic performance. Journal of the Academy of Nutrition and Dietetics. 116(3), 501-528. doi: 10.1016/j.jand.2015.12.006 VIEW ITEM 